\title{
Psidium guajava leaves assisted green synthesis of metallic nanoparticles: a review
}

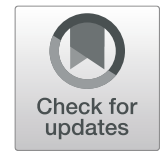

Shriniwas P. Patil ${ }^{1 *}$ (D) and Pradip M. Rane ${ }^{2}$

\begin{abstract}
Background: Several attempts have been made for green synthesis of metallic nanoparticles, revealing the significance of plant extracts in reducing metal source to nanoparticles and applications in various domains of science.

Main body: Psidium guajava (guava) is evergreen, edible fruit-bearing plant, belonging to family Myrtaceae. Its leaves are reported to contain several phytochemicals like tannins, glycosides, terpenes, and triterpenes. This article focus on applications of Psidium guajava leaves extract in fabrication of nanoparticles of various metals like silver, gold, titanium dioxide, zinc oxide, and copper oxide. In respective research attempts, these metallic nanoparticles were evaluated for one or more applications like anti-microbial activity and/or photocatalytic activity.

Conclusion: Use of polar extract of guava leaves indicated involvement of its polar phyto-compounds in reducing the metal source and stabilizing the nanoparticles. In conclusion, it could be noted that metal nanoparticles have better anti-microbial activity and photocatalytic potential over aqueous leaves extract.
\end{abstract}

Keywords: Psidium guajava, Phytochemicals, Metal nanoparticles, Anti-microbial potential, Photocatalytic activity

\section{Background}

Considering the wide range of applications of metal nanoparticles, several attempts were made for their synthesis. For this, researchers mainly focus on green route of their synthesis to avoid hazardous chemicals and physical abrasion based on possible accidents involved in chemical and physical methods available for the fabrication of metallic nanoparticles. Green synthesis of metallic nanoparticles includes reduction of metal ion source compound by extract (mainly of polar solvent) of any organ on plant and capping of newly synthesized nanoparticle by phytochemicals present in the extract [1].

Psidium guajava (common name-guava) (Fig. 1), a large dicotyledonous shrub or small evergreen tree, belonging to the family Myrtaceae, native to tropical America, is a well-known tree with edible fruits [2]. Almost all parts have history of therapeutic application [3]. This plant grows to full growth in wide range of soil

\footnotetext{
* Correspondence: patislp111@gmail.com

'Department of Pharmacognosy, SCES's Indira College of Pharmacy, Pune

411038 , India

Full list of author information is available at the end of the article
}

types [4]. Guava leaves (Fig. 2) are greenish, simple, exstipulate with short petiole, entire margin, ovate or acuminate apex, rounded to sub-acuminate base, and pinnate/reticulate venation. The leaves are $10-12 \mathrm{~cm}$ long and $5-7 \mathrm{~cm}$ wide.

The present review aimed toward summarizing the materialistic requirements, procedures employed for green synthesis of metal nanoparticles using P. guajava leave extract and their different applications. Most of the research articles, I referred for this review were published on well-recognized journals of international databases like, Elsevier-ScienceDirect (http://www. sciencedirect.com), Springer (http://link.springer.com), MDPI, Innovare Academic Sciences (https://innovareacademics.in/), and PubMed (http://www.ncbi.nlm.nih.-gov>pubmed).

Prior to summarize the data about metallic nanoparticle synthesis, it will be worthy to have a look on phytochemicals reported so far from $P$. guajava leaves and thereby their pharmacological potentials as one of the older applications. 


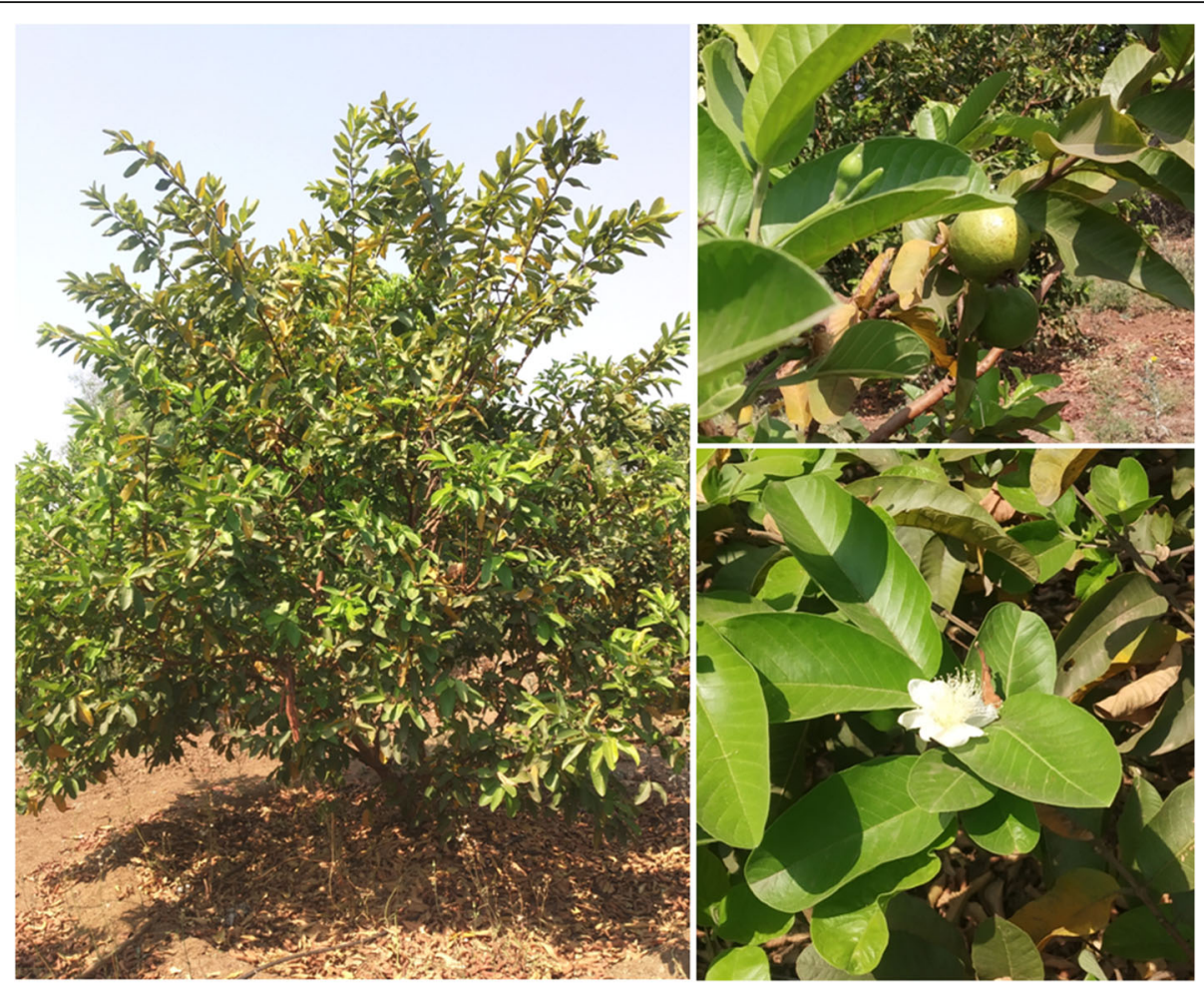

Fig. 1 Psidium guajava plant in its habitat, with few fruits and flowers

\section{Main text}

\subsection{Phytochemical prospection of guava leaves}

Matsuo et al. firstly isolated $(+)$-gallocatechin from $P$. guajava leaves [5], then Begum et al. isolated triterpenoids guavanoic acid, guavacoumaric acid, asiatic acid, jacoumaric acid, $2 \alpha$-hydroxyursolic acid, isoneriucoumaric acid, $\beta$-sitosterol-3-O- $\beta$-D-glucopyranoside, and ilelatifol D from the leaves of P. guajava [6]. They also found $\alpha$-pinene, $\beta$-pinene, limonene, isopropylalcohol, menthol, terpenyl acetate, caryophyllene, longicyclene, and $\beta$-bisabolene as components of essential oil. Glycodises like guavin B, guavin A, isostrictinin, strictinin amritoside or ellagic acid 4-gentiobioside, and pedunculagin were isolated from $P$. guajava.
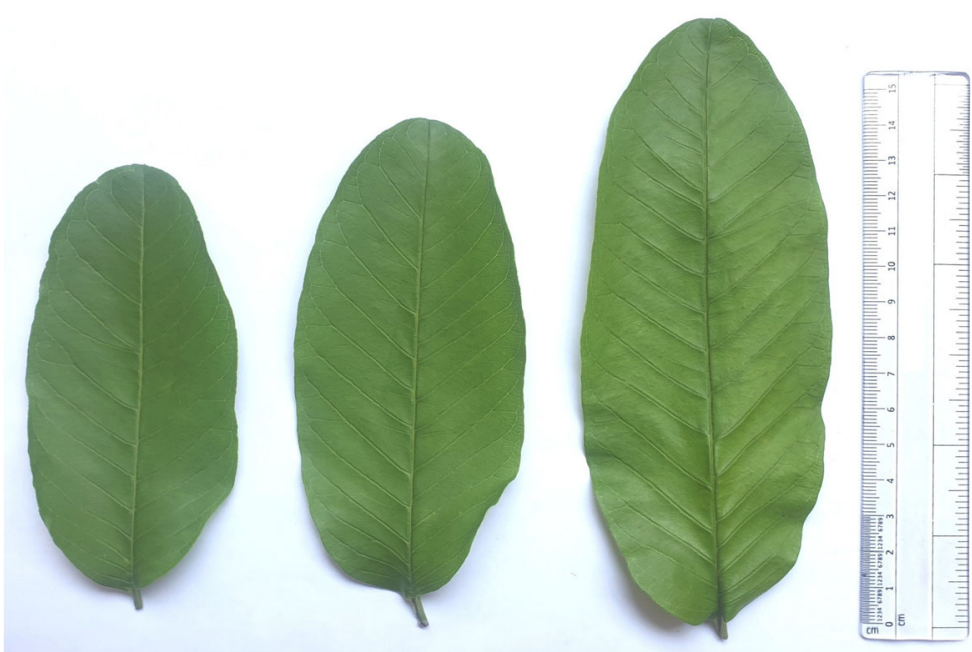

Fig. 2 Psidium guajava leaves 
Flavonoids including quercetin and its glycosides have also been isolated from guava leaves (Fig. 3) [7, 8].

\subsection{Pharmacological activities of guava leaves}

Since long back, guava leaves have been used in treatment of various illnesses. However, their pharmacological activities have been proved scientifically in the last few decades. Based on the isolation of phytochemicals from guava leaves, and phytochemical prospection, phyto-compounds present in leaves are supposed to possess relevant biological activity. Pharmacological activity of guava leaves with model used for screening has been mentioned in Table 1.

\subsection{Metallic nanoparticles green synthesized using guava} leaves

Several researchers have successfully attempted the synthesis of metallic nanoparticles using mainly aqueous extract of $P$. guajava leaves. Use of water for extraction reveals the presence of primary and secondary metabolites, mainly of polar nature. Not reported so far, but primary metabolites like mono- and oligo-saccharides, polar proteins may also be present in the extract. However, polar secondary metabolites including glycosides and polyphenolics like flavonoids and tannins (as reported in earlier section) could be responsible for reduction of metal ions to nanoparticles.<smiles>CC(=O)OC1(C)CCC2(C(=O)O)CCC3(C)C(=CCC4C5(C)CC(O)C(O)C(C)(C)C5CCC43C)C2C1C</smiles><smiles>CC1CCC2(C(=O)O)CCC3(C)C(=CCC4C5(C)CC(O)C(O)C(C)(COC(=O)C=Cc6ccc(O)cc6)C5CCC43C)C2C1C</smiles>

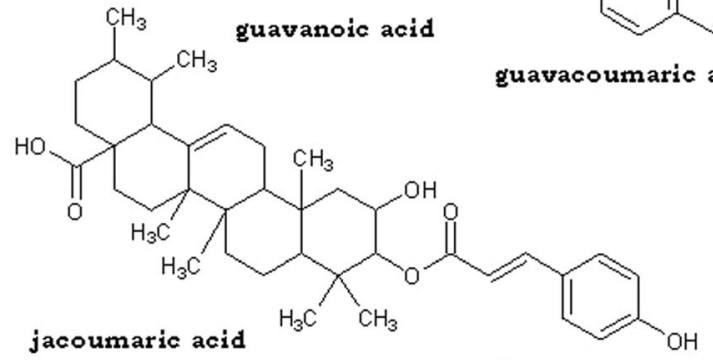

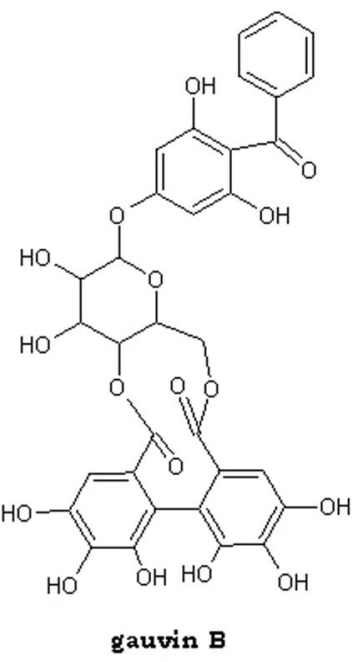<smiles>CC1CCC2C(=O)CCC3(C=CC4C5CC(O)C(O)C(C)(C)C5CCC4(C)C23C)C1C</smiles>

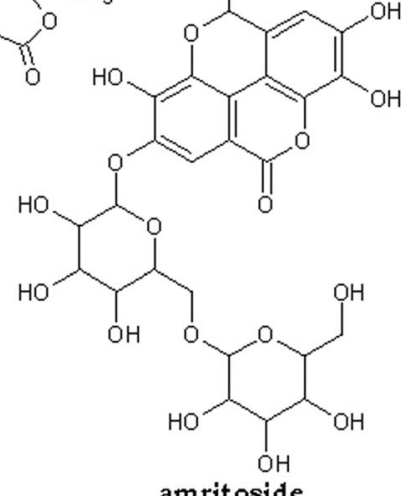

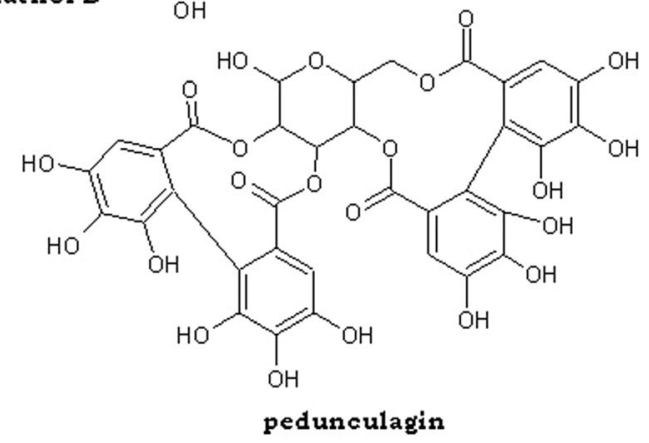

Fig. 3 Phytochemical constituents present in P.guajava leaves 
Table 1 Pharmacological activities of Psidium guajava leaves

\begin{tabular}{|c|c|c|}
\hline Pharmacological activity & Model used in screening & Reference \\
\hline Antibacterial activity & Broth micro-dilution assay and MIC determination & [9] \\
\hline Anti-oxidant activity & DPPH free radical scavenging assay & [10] \\
\hline Anti-diarrheal effect & Castor oil-induced diarrhea (COID) model & \\
\hline \multirow[t]{2}{*}{ Anti-diabetic activity } & Alloxan induced diabetic test model & [11] \\
\hline & Streptozotocin (STZ)-induced diabetes mellitus mode & [12] \\
\hline Anti-hyperlipidemic activity & Lipase inhibition & [13] \\
\hline \multirow[t]{3}{*}{ Cardioprotective effects } & Ischemia-reperfusion injury using isolated perfused rat hearts & [14] \\
\hline & lonotropic effect & [15] \\
\hline & Contractile effect on aortic rings in rat & [16] \\
\hline Hypotensive effect & Hypertensive Dahl salt-sensitive rats & [12] \\
\hline Anti-proliferative activity & Methylene blue assay & [17] \\
\hline In vivo cytotoxic activity & Brine shrimp cytotoxicity & [18] \\
\hline In vitro anticancer assay & MTT assay & \\
\hline Anti-tumor activity & Potato disk assay & \\
\hline Anti-inflammatory potential & Electrophoretic mobility shift assay & \\
\hline \multirow[t]{4}{*}{ Hepatoprotective activity } & Carbon tetrachloride-induced liver toxicity & [19] \\
\hline & Paracetamol-induced liver toxicity & \\
\hline & Thioacetamide induced liver toxicity & \\
\hline & Ethanol-induced liver toxicity & [20] \\
\hline
\end{tabular}

\subsection{Gold nanoparticles}

Use of $P$. guajava leave extract in fabrication of nanoparticles was initiated by Taha et al. in 2013, by synthesizing gold nanoparticles using $25 \times 10^{-3} \mathrm{M}$ gold (III) chloride hydrate $\left(\mathrm{HAuCl}_{4} \cdot 3 \mathrm{H}_{2} \mathrm{O}\right)$ as a gold ions donor, which were reduced to nanoparticles by aqueous extract (prepared by extracting about $1 \mathrm{~g}$ of leave powder with 100 $\mathrm{mL}$ of de-ionized water for $24 \mathrm{~h}$ ). They found few irregular but mostly spherical gold nanoparticles [21].

\subsection{Titanium dioxide nanoparticles}

In 2014, Santhoshkumar et al. attempted green synthesis of titanium oxide nanoparticles using aqueous extract (prepared by extracting about $20 \mathrm{~g}$ of leave powder with $250 \mathrm{~mL}$ of doubled-distilled water at $60{ }^{\circ} \mathrm{C}$ for $15 \mathrm{~min}$ ) and $0.1 \mathrm{mM} \mathrm{TiO}(\mathrm{OH})_{2}$. They found titanium oxide nanoparticles spherical in shape. Further, they evaluated their antimicrobial activity against $A$. hydrophila, E. coli, $P$. mirabilis, $S$. aureus $P$. aeruginosa, and antioxidant activity using sulfuric acid, sodium phosphate, and ammonium molybdate, DPPH (2,2-diphenyl-1-picrylhydrazyl) radical scavenging models [22].

\subsection{Silver nanoparticles}

So far numerous attempts were made for synthesis of silver nanoparticles using different plant extracts. The main reason lies in their application against variety of microorganisms by one or a combination of more than one mechanism of anti-microbial activity, apart from different applications in different domains. Considering this wide range of utilities, several times, silver nanoparticles have also been tried to get prepared using $P$. guajava leave extract. Most of these researchers used $1 \mathrm{mM}$ silver nitrate $\left(\mathrm{AgNO}_{3}\right)$ as silver ions donor to be reduced by aqueous extract of $P$. guajava leaves, prepared in double-distilled water [23-25]; however, Dama et al. used methanol as solvent for extraction. They found silver nanoparticles in spherical shape and evaluated their anti-microbial efficacy against microbes like E.coli, S.aureus, and P.aeruginosa [26].

\subsection{Tin oxide nanoparticles}

M. Kumar et. al. proved that aqueous extract of $P$. guajava leaves could be utilized in reduction of $2.1 \mathrm{M}$ tin (IV) chloride or stannic chloride $\left(\mathrm{SnCl}_{4}\right)$ to sphericalshaped tin oxide nanoparticles. Additionally, researchers studied their photocatalytic activity using dye reactive yellow 186/vinyl disulphone RY 186 [27].

\subsection{Zero-valent iron nanoparticles}

A couple of years ago, Somchaidee et al. fabricated zerovalent iron nanoparticles using $P$. guajava extract prepared by extraction of about $4 \mathrm{~g}$ of leaf powder with 100 $\mathrm{mL}$ of three solvents, namely, water, ethanol, hydroethanolic solvent at $60{ }^{\circ} \mathrm{C}$ for $15 \mathrm{~min}$. These extracts were then separately treated with ferric chloride $\left(\mathrm{FeCl}_{3}\right)$ 
solution, which later formed zero-valent iron nanoparticles. Then, researchers tried their efficiency in photocatalytic degradation of dye methylene blue [28].

\subsection{Zinc oxide nanoparticles}

Last year, Saha et al. explored the use of extract of $P$. guajava leaves prepared by maceration of about $10 \mathrm{~g}$ of leaf powder with $100 \mathrm{~mL}$ of double distilled water for 24 $\mathrm{h}$, in green synthesis of zinc oxide nanoparticles from zinc oxide donor, $1 \mathrm{M}$ zinc acetate $\left(\mathrm{Zn}\left(\mathrm{CH}_{3} \mathrm{COO}\right)_{2}\right)$. After characterization, they determined photocatalytic activity (using dye methylene blue) and antimicrobial activity (against E. coli and S. aureus) of so synthesized zinc oxide nanoparticles [29].

\subsection{Copper oxide nanoparticles}

Recent attempt of $P$. guajava leaves extract use was made in synthesis of copper oxide nanoparticles where about $4 \mathrm{~g}$ of copper acetate monohydrate $\left(\mathrm{Cu}\left(\mathrm{CH}_{3-}\right.\right.$ $\mathrm{COO})_{2}$ ) in $10 \mathrm{~mL}$ de-ionized water was used as copper oxide ion donor [30]. Here, reduction and stabilization of copper oxide nanoparticles were achieved by aqueous extract of $P$. guajava leaves prepared by extraction of about $10 \mathrm{~g}$ of leaves powder with $100 \mathrm{~mL}$ of de-ionized water at $80^{\circ} \mathrm{C}$ for $3 \mathrm{~h}$. They found these copper oxide nanoparticles spherical in shape. Further, they determined their efficiency in photocatalytic degradation of dyes Nile blue and RY 160.

\subsection{Screening of antimicrobial activity of $P$. guajava} leaves assisted synthesis of metallic nanoparticles

Most of the metallic nanoparticles synthesized using $P$. guajava leaves have been evaluated for their antimicrobial potential by slightly different methods possessing some common aspects. Generally, for this, selected Gram-positive and Gram-negative bacteria sub-cultured in nutrient broth at $37^{\circ} \mathrm{C}$ for $24 \mathrm{~h}$ and followed well diffusion assay. Then, a loopful of bacterial culture was swabbed over the solidified Mueller Hinton agar plates and incubated for $37^{\circ} \mathrm{C}$ for $24 \mathrm{~h}$. Finally, anti-bacterial activity is revealed by occurrence of zone of inhibition around the well (Table 2).

\subsection{Photocatalytic degradation of dyes by P. guajava leaves assisted synthesis of metallic nanoparticles}

Similar to antimicrobial activity, the potential of most of metallic nanoparticles synthesized using $P$. guajava extract to cause photocatalytic degradation of dyes has also been determined, sharing common mechanism and deferring in dyes used. Photocatalysis is electromagnetic irradiation-induced series of chemical reactions including reduction and oxidation. When photons (in the form of light rays) irradiates the material with energy equal to or higher than its bandgap, electron in the conduction band (CB) jump to the valence band $(\mathrm{VB})$ through the bandgap leaving positive holes. This leads to the formation of reactive oxygen species (ROS), which is the significant outcome of photocatalysis as it affects surrounding thereby used in degradation of dye and pollutants [31] and antibacterial potential [32] (Fig. 4). Here, absorbance of irradiation by material can be enhanced by doping, photosensitization of semiconductor, and use of plasmonic. The common approach of evaluating the photocatalytic efficiency is to compare between the initial concentrations of the unwanted compounds (e.g., dye as pollutant) with the concentration of these compounds after the photocatalytic reactions using the equation:

$$
\ln \frac{C o}{C t}=k t
$$

Tin oxide [27], zero-valent iron oxide [28], zinc oxide [29], and copper oxide [30] nanoparticles, green synthesized using aqueous extract of Psidium guajava leaves have been evaluated for their photocatalytic activity using dyes RY160 and RY186, methylene blue, or Nile blue.

Table 2 Anti-microbial activity (in the form of zone of inhibition) exhibited by P.guajava leaves assisted synthesized nanoparticles against selected microbes

\begin{tabular}{lllll}
\hline Nanoparticle & \multicolumn{2}{l}{ Zone of inhibition (in mm) } & \multicolumn{2}{c}{ Reference } \\
\cline { 2 - 5 } & E.coli & S.aureus & & \\
\hline ZnO-chitosan nanocomposite & $28.6 \pm 0.1$ & $30.3 \pm 0.2$ & 19 & {$[29]$} \\
$\mathrm{TiO}_{2}$ & 23 & 25 & $23.3 \pm 1.7$ & {$[22]$} \\
Silver & & & $8 \pm 0.09$ & {$[23]$} \\
Silver & $11 \pm 0.14$ & 10 & 10.5 & {$[26]$} \\
Silver & 9.5 & 12 & & {$[24]$} \\
Silver & 12 & & {$[25]$} \\
\hline
\end{tabular}




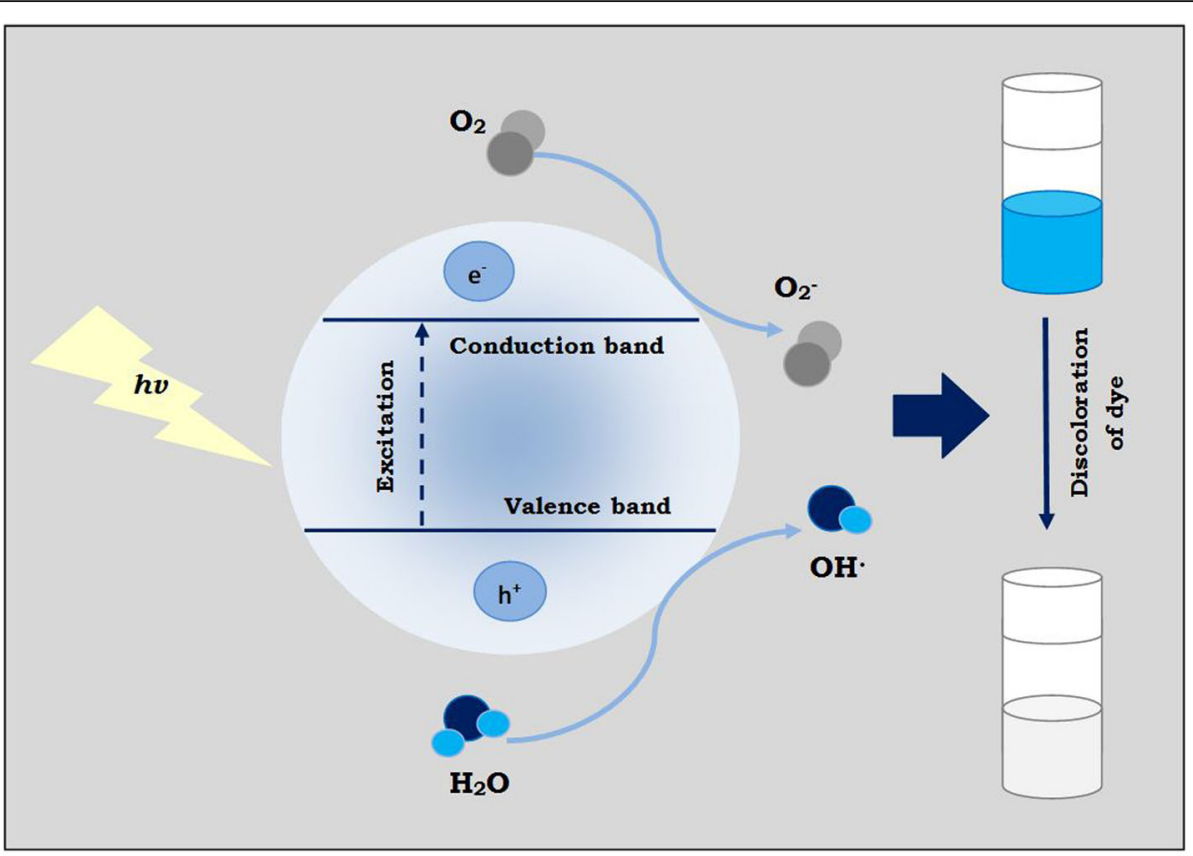

Fig. 4 Nanoparticles assisted photocatalysis and discoloration of dye

\subsection{Future prospects}

From this literature survey made for applications of $P$. guajava leaf extracts for the green synthesis of metal and metal oxide nanoparticles, it is clear that due to presence of variety of secondary metabolites which may have pharmacologically beneficial effect, responsible for reduction of donor compound to its corresponding nanoparticles and also for stabilizing them to particular size and shape. So, there are two different fronts at which research could be made: The first one is exploring the new applications of existing nanoparticles synthesized from P.guajava leaves. There are few biological aspects, where an active entity has to be penetrated inside the cell. Due to the high penetration ability of nanoparticles, antimicrobial and anti-cancer/anti-proliferative activities of existing as well as nanoparticles of different metals those could be synthesized from $P$. guajava leaves can be tried on different cell lines (other than those studied so far) and different microorganisms (other than those studied so far), respectively. The second approach involves eco-friendly synthesis of new nanoparticles of metals and metal oxides (other than those green synthesized so far) and/or evaluation of their potential in different scientific domains like cadmium sulfide antimicrobial nanoparticles, $\mathrm{Eu}_{3}{ }^{+}$doped $\mathrm{Y}_{2} \mathrm{SiO}_{5}$ nanophosphors to be used in light-emitting diodes (LEDs), cupric oxide nanoparticles to be used in dye-sensitized solar cells (DSSCs), and cerium oxide nanoparticles as an anti-obesity pharmaceutical formulation.

\section{Conclusion}

Based on this review, it can be concluded that $P$. guajava leaf extracts can be used for green synthesis of metallic nanoparticles having a wide range of applications in various scientific domains, including antimicrobial and photocatalytic activities.

\section{Abbreviations}

CB: Conduction band; COID: Castor oil-induced diarrhea; DPPH: 2,2-Diphenyl1-picrylhydrazyl; MDPI: Multidisciplinary Digital Publishing; VB: Valence band; ROS: Reactive oxygen species; RY160 and 186: Reactive yellow 160 and 186; STZ: Streptozotocin

\section{Acknowledgements \\ The authors of this manuscript are thankful to Dr. Ravindra D. Patil, Principal, TME Society's J. T. Mahajan College of Engineering, Faizpur, Dist. Jalgaon, for his encouragement and also for providing internet and library facilities at the college premises to access the articles and books to carry out this review.}

\section{Authors' contributions}

SPP selected the topic and written manuscript. PMR drew figures and diagrams. All authors read and approved the final manuscript.

\section{Funding}

No funding received for this research work.

\section{Availability of data and materials}

No additional data and material other than the manuscript is to produce.

Ethics approval and consent to participate

Not applicable.

Consent for publication

Not applicable.

Competing interests

None. 


\section{Author details}

'Department of Pharmacognosy, SCES's Indira College of Pharmacy, Pune 411 038, India. ${ }^{2}$ J.T. Mahajan Polytechnic, Nhavi road, Faizpur, Jalgaon 425524, India.

Received: 9 July 2020 Accepted: 16 November 2020

Published online: 03 December 2020

\section{References}

1. Patil SP (2020) Calotropis gigantea assisted green synthesis of nanomaterials and their applications: a review. Beni-Suef Univ J Basic Appl Sci 9:14. https:// doi.org/10.1186/s43088-020-0036-6

2. Dakappa SS, Adhikari R, Timilsina SS, Sajjekhan S (2013) A review on the medicinal plant Psidium guajava Linn. (Myrtaceae). J Drug Deliv Ther. 3(2): 162-168. https://doi.org/10.22270/jddt.v3i2.404

3. Nwinyi O, Chinedu SN, Ajani OO (2008) Evaluation of antibacterial activity of Pisidium guajava and Gongronema latifolium. J Med Plants Res. 2(8):189-192

4. Jiminez-Escrig A, Rincon M, Pulido R, Saura-Calixto F (2001) Guava fruit (Psidium guajava L.) as a new source of antioxidant dietary fiber. J Agric Food Chem. 49(11):5489-5493. https://doi.org/10.1021/jf010147p

5. Matsuo T, Hanamure N, Shimoi K, Nakamura Y, Tomita I (1994) Identification of (+)-gallochatechin as a bio-antimutagenic compound in Psidium guava leaves. Phytochemistry 36(4):1027-1029. https://doi.org/10.1016/S00319422(00)90484-9

6. Begum S, Siddiui BS, Hassan SI (2002) Triterpenoids from Psidium guajava leaves. Nat Prod Letters 16(3):173-177. https://doi.org/10.1080/ 10575630290004251

7. Arima $\mathrm{H}$ and Danno G. Isolation of antimicrobial compounds from Guava (Psidium guajava L.) and their structural elucidation. Biosci Biotechnol Biochem 2002; 66(8):1727-30. do: 10.1271/bbb.66.1727

8. Abdel WSM, Hifawy MS, El GoharyandM HM. Isak. Study of carbohydrates, lipids, protein, flavonoids, vitamin $C$ and biological activity of Psidium guayava L. growing in Egypt. Egypt J Biomed Sci. 2004; 16: 35-52.

9. Neviton RS, Diógenes AGC, Michelle SS, Celso VN, Benedito PDF. An evaluation of antibacterial activities of Psidium guajava L.). 2005; Brazilian Arch Biol Technol 48 (3): 429-436. doi: https://doi.org/10.1590/S151689132005000300014

10. Suganya T, Fumio I, Siriporn O (2007) Antioxidant active principles isolated from Psidium guajava grown in Thailand. Sci Pharm 75:179-193. https://doi. org/10.3797/scipharm.2007.75.179

11. Mazumdar S, Akter R, Talukdar D (2015) Anti-diabetic and anti-diarrheal effects of ethanolic extract of (L.) Bat. leaves in Wister rats. Asian Pac J Trop Biomed 5(1):10-14

12. Ojewole JA (2005) Hypoglycemic and hypotensive effects of Psidium guajava Linn. (Myrtaceae) leaf aqueous extract. Methods Findings Exp. Clin Pharm 27(10):689-695. https://doi.org/10.1358/mf.2005.27.10.948917

13. Tella T, Masola B, Mukaratirwa S (2019) The effect of Psidium guajava aqueous leaf extract on liver glycogen enzymes, hormone sensitive lipase and serum lipid profile in diabetic rats. Biomed Pharmacother 109:24412446. https://doi.org/10.1016/j.biopha.2018.11.137

14. Yamashiro S, Noguchi S, Matsuzaki T, Miyagi K, Nakasone J, Sakanashi M et al (2003) Cardioprotective effects of extracts from Psidium guajava L. and Limonium wrightii, Okinawan medicinal plants, against ischemia reperfusion injury in perfused rat hearts. Pharmacology 67(3):128-135. https://doi.org/10. 1159/000067799

15. Conde Garcia EA, Nascimento VT, Santiago Santos AB (2003) Inotropic effects of extracts of Psidium guajava L. (guava) leaves on the Guinea pig atrium. Brazilian J Med Biol Res 36(5):661-668. https://doi.org/10.1590/ S0100-879X2003000500014

16. Olatunji-Bello I, Odusanya AJ, Raji I, Ladipo CO (2007) Contractile effect of the aqueous extract of Psidium guajava leaves on aortic rings in rat Fitoterapia 78(3):241-243. https://doi.org/10.1016/j.fitote.2006.11.007

17. Sul'ain MD, Zazaliand KE, Ahmad N (2012) Screening on anti-proliferative activity of Psidium guajava leaves extract towards selected cancer cell lines. J US China Med Sci 9:30-37

18. Ashraf A, Sarfraz RA, Rashid MA, Mahmood A, Shahid M, Noor N (2015) Chemical composition, antioxidant, antitumor, anticancer and cytotoxic effects of Psidium quajava leaf extracts. Pharma Biol 54(10):1971-1981. https://doi.org/10.3109/13880209.2015.1137604

19. Roy CK, Kamath JV, Asad M (2006) Hepatoprotective activity of Psidium guajava Linn. leaf extract. Indian J Exp Biol. 44(4):305-311
20. Hung-Hui C, Po-Hua W, Diana L, Yun-Chiehand P, Ming-Chang W (2011) Hepatoprotective effect of guava (Psidium guajava L.) leaf extracts on ethanol-induced injury on Clone 9 rat liver cells. Food Nutr Sci 2:983-988

21. Taha A, Shamsuddin M (2013) Biosynthesis of gold nanoparticles using Psidium guajava leaf extract. Malaysian J Fundam Appl Sci. 9(3):119-122

22. Santhoshkumar T, Rahuman AA, Jayaseelan C, Rajakumar G, Marimuthu S, Kirthi AV, Velayutham K, Thomas J, Venkatesan J, Kim S-K (2014) Green synthesis of titanium dioxide nanoparticles using Psidium guajava extract and its antibacterial and antioxidant properties. Asian Pac J Trop Med 7(12):968-976

23. Bose D, Chatterjee S (2016) Biogenic synthesis of silver nanoparticles using guava (Psidium guajava) leaf extract and its antibacterial activity against Pseudomonas aeruginosa. Appl Nanosci 6:895-901. https://doi.org/10.1007/ s13204-015-0496-5

24. Geetha V (2017) Green synthesis of silver nanoparticles from Psidium guajava leaves and its antibacterial activity. Int J Bioassays 6. 7(5441):5443. https://doi.org/10.21746/ijbio.2017.07.003

25. Sharmila C, Ranjith Kumar R, Chandar Shekar B. 2018. Psidium quajava: a novel plant in the synthesis of silver nanoparticles for biomedical applications. Asian J Pharm Clin Res, 11(1): 341-345. doi: https://doi.org/10. 22159/ajpcr.2018.v11i1.21999

26. Dama LB, Mane PP, Pathan AV, Chandarki MS, Sonawane SR, Dama SB, Chavan SR, Chondekar RP, Vinchurkar AS (2016) Green synthesis of silver nanoparticles using leaf extract of Lawsonia inermis and Psidium guajava and evaluation of their antibacterial activity. Science Res Rep 6(2):89-95

27. Kumar M, Mehta A, Mishra A, Singh J, Rawat M, Basu S (2017) Biosynthesis of tin oxide nanoparticles using Psidium quajava leave extract for photocatalytic dye degradation under sunlight. https://doi.org/10.1016/j. matlet.2017.12.074

28. Somchaidee P, Tedsree K (2018) Green synthesis of high dispersion and narrow size distribution of zero-valent iron nanoparticles using guava lea (Psidium guajava L) extract. Adv Nat Sci Nanosci Nanotechnol. 9. 035006 (9 pp), https://doi.org/10.1088/2043-6254/aad5d7

29. Saha R, Subramani K, Petchi Muthu Raju SAK, Rangaraj S, Venkatachalam R (2018) Psidium guajava leaf extract-mediated synthesis of $\mathrm{ZnO}$ nanoparticles under different processing parameters for hydrophobic and antibacterial finishing over cotton fabrics. Progress Organic Coatings 124:80-91. https:// doi.org/10.1016/j.porgcoat.2018.08.004

30. Singh J, Kumar V, Kim K-H, Rawat M (2019) Biogenic synthesis of copper oxide nanoparticles using plant extract and its prodigious potential for photocatalytic degradation of dyes. Environ Res 177:108569. https://doi.org/ 10.1016/j.envres.2019.108569

31. Liu M, Zhang D, Chen S, Wen T (2016) Loading Ag nanoparticles on Cd(II) boron imidazolate framework for photocatalysis. J. Solid State Chem. 237: 32-35. https://doi.org/10.1016/j.jssc.2016.01.016

32. Fakhri A, Naji M (2017) Degradation photocatalysis of tetrodotoxin as a poison by gold doped $\mathrm{PdO}$ nanoparticles supported on reduced graphene oxide nanocomposites and evaluation of its antibacterial activity. J Photochem Photobiol B 167:58-63. https://doi.org/10.1016/j.jphotobiol.2016. 12.027

\section{Publisher's Note}

Springer Nature remains neutral with regard to jurisdictional claims in published maps and institutional affiliations.

\section{Submit your manuscript to a SpringerOpen ${ }^{\circ}$ journal and benefit from:}

- Convenient online submission

- Rigorous peer review

- Open access: articles freely available online

- High visibility within the field

- Retaining the copyright to your article

Submit your next manuscript at $>$ springeropen.com 